\title{
Catalytic Processes for The Valorization of Biomass Derived Molecules
}

\author{
Claudia Espro 1,*(D) and Francesco Mauriello $2, *$ (D) \\ 1 Dipartimento di Ingegneria, Università di Messina, Contrada di Dio-Vill. S. Agata, I-98166 Messina, Italy \\ 2 Dipartimento DICEAM, Università Mediterranea di Reggio Calabria, Loc. Feo di Vito, \\ I-89122 Reggio Calabria, Italy \\ * Correspondence: espro@unime.it (C.E.); francesco.mauriello@unirc.it (F.M.); Tel.: +39-090-6765264 (C.E.); \\ +39-0965-1692278 (F.M.)
}

Received: 30 July 2019; Accepted: 6 August 2019; Published: 8 August 2019

\section{Introduction}

Industrial chemistry is changing its fossil distinctiveness into a new green identity by using renewable resources. Biomasses, produced and used in a cyclical way, constitute an important environmentally friendly resource for the production of energy, chemicals, and biofuels $[1,2]$. To this regard, abundant and inedible lignocellulosic biomasses have attracted a lot of attention being not in competition with agricultural land and food production and, therefore, representing renewable feedstocks for modern biorefineries. The three main components of lignocellulosic biomasses are cellulose, hemicellulose, and lignin, which can be converted into energy (biogas and $\mathrm{H}_{2}$ ), liquid biofuels, and into a pool of platform molecules including sugars, polyols, alcohols, aldehydes, ketones, ethers, esters, acids, and aromatics compounds [3-7]. However, in order to develop efficient catalytic processes for the selective production of desired products from lignocellulose, a deep understanding of the molecular aspects of the basic chemistry and reactivity of biomass derived molecules is still necessary.

This Special Issue aims to cover recent progresses in the catalytic valorization of cellulose, hemicellulose and lignin model molecules promoted by novel heterogeneous systems for the production of energy, fuels and chemicals. In this context, it is worth to highlight some recent research advances. Among many, hydrogenation/hydrogenolysis [8,9] and transfer hydrogenolysis [10-12] of cellulose, hemicellulose, lignin, C6-C3 polyols, furan derivatives and aromatic ethers represent a core technology of modern biorefineries. Glycerol (C3 polyol) and glycidol (2,3-epoxy-1-propanol) can be converted into hydrogen (via APR process), C3-C1 alcohols, as well as to cyclic acetals and ketals [13-16]. Accordingly, reforming processes are surely a new way for the production of $\mathrm{H}_{2}$ and liquid hydrocarbons from lignocellulosic biomasses or their derived molecules [17-20]. At the same time, biomasses can be directly converted into liquid fuels and bio-oils via pyrolysis (thermal degradation process in absence of added oxygen) [21] or used as starting materials for the production of vegetable oils that are efficiently used in several energetic application [22,23]. Finally, a recent trend is surely the production of aromatics, including BTX compounds (benzene-toluene-xylene), starting from lignin, sugars and aromatic ethers, and esters in the framework of the so-called "lignin-first biorefinery" [24-28].

\section{The Contents of the Special Issue}

In this special issue, several fields of research on the catalytic valorization of biomasses and their relative molecules are covered. Therefore, we would like to sincerely thank all the authors who contributed with their excellent contributions to this special issue that includes six articles (three reviews among them).

Martín et al. propose a natural zeolite (Chilean) as an innovative catalyst for bio-oil upgrade processes [29]. The results clearly show that Chilean-zeolites efficiently increase both quality and 
stability of the bio-oil obtained from the catalytic pyrolysis of the Chilean native oak. In particular, zeolite acid sites allow the decrease of oil viscosity as a consequence of the increase of the concentration of hydrocarbons, alcohols and aldehydes during the storage practice. At the same time, the presence of Brønsted acid sites on Chilean-zeolites promotes the reduction of carbonyl and alcoholic groups of bio-oil, even after storage.

The hydro-isomerization upgrading of vegetable oil-based insulating oil was presented by Dieu-Phuong Phan and Eun Yeol Lee [30]. In their review, they demonstrated that vegetable oils can be a valid feedstock of insulating oils for electric transformers presenting the effect of (i) metal phase, (ii) acid sites, and (iii) pore structure on the catalytic hydroisomerization processes. At the same time, the influence of blending processes on the physico-chemical properties of these alternative oils are also presented. Moreover, in their contribution, authors pointed out some of the drawbacks related to vegetable oil-based insulating oils (e.g., high pour points, minor aging, and higher viscosity).

Prof. Jose A. Lopez-Sanchez and co-workers demonstrated the influence of alkaline treatment of H-ZSM-5 catalyst for the production of p-xylene and other aromatic compounds starting from bioderived sugars and ethylene [31]. Authors show that the alkaline treatment allows obtaining a series of catalysts characterized by a mesoporous structure preserving the typical crystallinity of the H-ZSM- 5 based zeolites. The key factor in driving the production of p-xylene from 2,5-dimethylfuran in high activity/selectivity was found to be the right compromise between acidity and mesoporosity of the alkaline H-ZSM-5 catalyst.

The use of an acid heterogeneous catalyst (Nafion NR50) for the synthesis of solketal from bio-glycidol was presented by Cucciniello et al. [32]. The Nafion NR50 system was found to be very efficient even at a very low catalyst loading, allowing a quantitative acetalization of glycidol into solketal under relative mild reaction conditions. Moreover, the catalyst can be re-used several times without any significant decrease in activity/selectivity.

The research group of Prof. Cavani and co-workers contributed a review on the use of mixed-oxide catalysts for the chemical-loop reforming (CRL) of bioethanol [33]. Authors pointed out how the different preparation methods drive the reactivity of spinels in the CLR of bioethanol. In particular, $\mathrm{M}-\mathrm{Fe}_{2} \mathrm{O}_{4}$ ferrospinels $\left(\mathrm{M}=\mathrm{Cu}, \mathrm{Co}, \mathrm{Mn}\right.$ ) were found to be very active in $\mathrm{H}_{2}$ production using several building block chemicals that can be obtained from ethanol (acetone, acetaldehyde, and C4 compounds) in the second loop. Furthermore, an easy recovery and reuse of the initial $\mathrm{M}-\mathrm{Fe}_{2} \mathrm{O}_{4}$ can be done.

In another review, the use of transfer hydrogenolysis approach for the reductive upgrading of lignocellulosic biomasses is presented [12]. The reductive valorization of cellulose, hemicellulose, lignin, and their relative derived/model molecules in absence of added $\mathrm{H}_{2}$ allows the production of several added value chemicals including acids, ethers, esters, aromatics, polyols, and alcohols. Furthermore, the use of simple organic molecules such as methanol, ethanol, 2-propanol, and formic acid as an indirect H-source may solve most of the problems related to the classic use of high-pressure molecular hydrogen (including safety hazards, expensive infrastructures, and costs related to the transport/storage of pressurized $\mathrm{H}_{2}$ ).

Funding: This research received no external funding.

Conflicts of Interest: All authors declare no conflict of interest.

\section{References}

1. Besson, M.; Gallezot, P.; Pinel, C. Conversion of Biomass into Chemicals over Metal Catalysts. Chem. Rev. 2014, 114, 1827-1870. [CrossRef] [PubMed]

2. Zhou, C.-H.; Xia, X.; Lin, C.-X.; Tong, D.-S.; Beltramini, J. Catalytic conversion of lignocellulosic biomass to fine chemicals and fuels. Chem. Soc. Rev. 2011, 40, 5588-5617. [CrossRef] [PubMed]

3. Espro, C.; Gumina, B.; Paone, E.; Mauriello, F. Upgrading Lignocellulosic Biomasses: Hydrogenolysis of Platform Derived Molecules Promoted by Heterogeneous Pd-Fe Catalysts. Catalysts 2017, 7, 78. [CrossRef] 
4. Chen, X.; Guan, W.; Tsang, C.-W.; Hu, H.; Liang, C. Lignin Valorizations with Ni Catalysts for Renewable Chemicals and Fuels Productions. Catalysts 2019, 9, 488. [CrossRef]

5. Shrotri, A.; Kobayashi, H.; Fukuoka, A. Cellulose Depolymerization over Heterogeneous Catalysts. Acc. Chem. Res. 2018, 51, 761-768. [CrossRef] [PubMed]

6. Delidovich, I.; Leonhard, K.; Palkovits, R. Cellulose and hemicellulose valorisation: An integrated challenge of catalysis and reaction engineering. Energy Environ. Sci. 2014, 7, 2803-2830. [CrossRef]

7. Xu, C.; Arancon, R.A.D.; Labidi, J.; Luque, R. Lignin depolymerisation strategies: Towards valuable chemicals and fuels. Chem. Soc. Rev. 2014, 43, 7485-7500. [CrossRef]

8. Ruppert, A.M.; Weinberg, K.; Palkovits, R. Hydrogenolysis goes bio: From carbohydrates and sugar alcohols to platform chemicals. Angew. Chem. Int. Ed. 2012, 51, 2564-2601. [CrossRef]

9. Li, N.; Wang, W.; Zheng, M.; Zhang, T. General Reaction Mechanisms in Hydrogenation and Hydrogenolysis for Biorefining. In Catalytic Hydrogenation for Biomass Valorization; Rinaldi, R., Ed.; Royal Society of Chemistry: Cambridge, UK, 2015; pp. 22-50.

10. Wang, D.; Astruc, D. The Golden Age of Transfer Hydrogenation. Chem. Rev. 2015, 115, 6621-6686. [CrossRef]

11. Gilkey, M.J.; Xu, B. Heterogeneous Catalytic Transfer Hydrogenation as an Effective Pathway in Biomass Upgrading. ACS Catal. 2016, 6, 1420-1436. [CrossRef]

12. Espro, C.; Gumina, B.; Szumelda, T.; Paone, E.; Mauriello, F. Catalytic Transfer Hydrogenolysis as an Effective Tool for the Reductive Upgrading of Cellulose, Hemicellulose, Lignin, and Their Derived Molecules. Catalysts 2018, 8, 313. [CrossRef]

13. Zhou, C.H.; Zhao, H.; Tong, D.S.; Wu, L.M.; Yu, W.H. Recent advances in catalytic conversion of glycerol. Catal. Rev. 2013, 55, 369-453. [CrossRef]

14. Mauriello, F.; Vinci, A.; Espro, C.; Gumina, B.; Musolino, M.G.; Pietropaolo, R. Hydrogenolysis vs. aqueous phase reforming (APR) of glycerol promoted by a heterogeneous Pd/Fe catalyst. Catal. Sci. Technol. 2015, 5, 4466-4473. [CrossRef]

15. Vicente, G.; Melero, J.A.; Morales, G.; Paniagua, M.; Martín, E. Acetalisation of bio-glycerol with acetone to produce solketal over sulfonic mesostructured silicas. Green Chem. 2010, 12, 899-907. [CrossRef]

16. Samoilov, V.O.; Onishchenko, M.O.; Ramazanov, D.N.; Maximov, A.L. Glycerol Isopropyl Ethers: Direct Synthesis from Alcohols and Synthesis by the Reduction of Solketal. ChemCatChem 2017, 9, 2839-2849. [CrossRef]

17. Cortright, R.D.; Davda, R.R.; Dumesic, J.A. Hydrogen from catalytic reforming of biomass-derived hydrocarbons in liquid water. Nature 2002, 418, 964-967. [CrossRef] [PubMed]

18. Davda, R.R.; Dumesic, J.A. Catalytic reforming of oxygenated hydrocarbons for hydrogen with low levels of carbon monoxide. Angew. Chem. Int. Ed. 2003, 42, 4068-4071. [CrossRef]

19. Vozniuk, O.; Agnoli, S.; Artiglia, L.; Vassoi, A.; Tanchoux, N.; Di Renzo, F.; Granozzi, G.; Cavani, F. Towards an improved process for hydrogen production: The chemical-loop reforming of ethanol. Green Chem. 2016, 18, 1038-1050. [CrossRef]

20. Hočevar, B.; Grilc, M.; Likozar, B. Aqueous Dehydration, Hydrogenation, and Hydrodeoxygenation Reactions of Bio-Based Mucic Acid over Ni, NiMo, Pt, Rh, and Ru on Neutral or Acidic Catalyst Supports. Catalysts 2019, 9, 286. [CrossRef]

21. Demirbas, A.; Arin, G. An overview of biomass pyrolysis. Energy Source 2002, 24, 471-482. [CrossRef]

22. Nagashree, A.N.; Champa, V.; Sumangala, B.V.; Nagabhushana, G.R. Suitability of natural vegetable seed oil as liquid dielectric coolant in an insulation system. In Proceedings of the 2015 International Conference on Emerging Research in Electronics, Computer Science and Technology (ICERECT), Mandya, India, 17-19 December 2015; pp. 429-434.

23. McShane, C.P. Relative properties of the new combustion-resist vegetable-oil-based dielectric coolants for distribution and power transformers. IEEE Trans. Ind. Appl. 2001, 37, 1132-1139. [CrossRef]

24. Mauriello, F.; Paone, E.; Pietropaolo, R.; Balu, A.M.; Luque, R. Catalytic transfer hydrogenolysis of lignin-derived aromatic ethers promoted by bimetallic Pd/Ni systems. ACS Sustain. Chem. Eng. 2018, 6, 9269-9276. [CrossRef]

25. Cozzula, D.; Vinci, A.; Mauriello, F.; Pietropaolo, R.; Müller, T.E. Directing the Cleavage of Ester C-O Bonds by Controlling the Hydrogen Availability on the Surface of Coprecipitated $\mathrm{Pd} / \mathrm{Fe}_{3} \mathrm{O}_{4}$. ChemCatChem 2016, 8, 1515-1522. [CrossRef] 
26. Paone, E.; Espro, C.; Pietropaolo, R.; Mauriello, F. Selective arene production from transfer hydrogenolysis of benzyl phenyl ether promoted by a co-precipitated $\mathrm{Pd} / \mathrm{Fe}_{3} \mathrm{O}_{4}$ catalyst. Catal. Sci. Technol. 2016, 6, 7937-7941. [CrossRef]

27. Cao, Z.; Dierks, M.; Clough, M.T.; de Castro, I.B.D.; Rinaldi, R. A convergent approach for a deep converting lignin-first biorefinery rendering high-energy-density drop-in fuels. Joule 2018, 2, 1118-1133. [CrossRef] [PubMed]

28. Renders, T.; den Bossche, G.V.; Vangeel, T.; Van Aelst, K.; Sels, B. Reductive catalytic fractionation: State of the art of the lignin-first biorefinery. Curr. Opin. Biotechnol. 2019, 56, 193-201. [CrossRef] [PubMed]

29. Alejandro Martín, S.; Cerda-Barrera, C.; Montecinos, A. Catalytic Pyrolysis of Chilean Oak: Influence of Brønsted Acid Sites of Chilean Natural Zeolite. Catalysts 2017, 7, 356. [CrossRef]

30. Phan, D.-P.; Lee, E.Y. Catalytic Hydroisomerization Upgrading of Vegetable Oil-Based Insulating Oil. Catalysts 2018, 8, 131. [CrossRef]

31. McGlone, J.; Priecel, P.; Da Vià, L.; Majdal, L.; Lopez-Sanchez, J.A. Desilicated ZSM-5 Zeolites for the Production of Renewable $p$-Xylene via Diels-Alder Cycloaddition of Dimethylfuran and Ethylene. Catalysts 2018, 8, 253. [CrossRef]

32. Ricciardi, M.; Falivene, L.; Tabanelli, T.; Proto, A.; Cucciniello, R.; Cavani, F. Bio-Glycidol Conversion to Solketal over Acid Heterogeneous Catalysts: Synthesis and Theoretical Approach. Catalysts 2018, 8, 391. [CrossRef]

33. Vozniuk, O.; Tabanelli, T.; Tanchoux, N.; Millet, J.-M.M.; Albonetti, S.; Di Renzo, F.; Cavani, F. Mixed-Oxide Catalysts with Spinel Structure for the Valorization of Biomass: The Chemical-Loop Reforming of Bioethanol. Catalysts 2018, 8, 332. [CrossRef]

(C) 2019 by the authors. Licensee MDPI, Basel, Switzerland. This article is an open access article distributed under the terms and conditions of the Creative Commons Attribution (CC BY) license (http://creativecommons.org/licenses/by/4.0/). 